\title{
Interferensi Gramatika Maharah Kitabah dan Penyebabnya Pada Mahasiswa Pascasarjana UIN Sunan Kalijaga
}

\author{
Ariadi Muliansyah \\ Universitas Islam Negri (UIN) Sunan Kalijaga Yogyakarta \\ ariadimuliansyah@gmail.com \\ R Umi Baroroh \\ Universitas Islam Nergri (UIN) Sunan Kalijaga Yogyakarta \\ barorohty@yahoo.co.id
}

\begin{abstract}
The purpose of this research is to find out the forms of grammatical interference that occur in graduate students of UIN Sunan Kalijaga. Interference is a language disorder that often occurs for language learners. Interference often occurs in all four language skills included in writing skills. Without realizing it, in writing scientific works students still often experience the first language interference, especially in the grammatical field. This research is a qualitative research with descriptive research type. The results found in this study indicate that the grammatical interference still occurs in the writing of graduate students of UIN Sunan Kalijaga. Researchers found 11 grammatical interference with details, 1 interference in the use of isim maushul, 5 interferences in making idahafah, 4 interferences in the use of fi'il (morphology), and 1 interference in the use of burf.
\end{abstract}

Keywords: Interference, grammatical, maharah kitabah

\begin{abstract}
Abstrak
Penelitian ini untuk mengetahui bentuk-bentuk interferensi gramatikal bahasa yang terjadi pada mahasiswa pascasarjana UIN Sunan Kalijaga. Interferensi adalah sebuah gangguan berbahasa yang sering terjadi bagi pembelajar bahasa. Interferensi sering terjadi dalam keempat keterampilan berbahasa termasuk dalam keterampilan menulis. Tanpa disadari dalam penulisan karya ilmiyah mahasiswa masih sering terjadi interferensi bahasa pertama, terutama dalam bidang gramatikal. Penelitian ini merupakan penelitian deskriptif kualitatif dengan jenis penelitian studi kasus. Hasil yang ditemukan dalam penelitian ini menunjukkan bahwa interferensi gramatika bahasa Indonesia masih terjadi dalam
\end{abstract}


penulisan bahasa Arab mahasiswa pascasarjana UIN Sunan Kalijaga. Peneliti menemukan 11 interferensi gramatikal dengan rincian, 1 interferensi dalam penggunaan isim maushul, 5 interferensi dalam pembuatan $i d h a f a h, 4$ interferensi dalam penggunaan fi'il (morfologi), dan 1 interferensi dalam penggunaan burf.

Kata kunci: Interferensi, gramatikal, maharah kitabah

\section{Pendahuluan}

Perkembangan keilmuan yang terjadi pada masa initerjadi sangat peasat,hal itu ditandai dengan semakin banyaknya pengkajian keilmuan yang dilakukan yang dilakukan di dalam maupun di luar negri. Dan sebagai upaya untuk bisa mengikuti perkembangan ilmu pengetahuan tersebut, maka penguasaan bahasa asing menjadi sesuatu yang sangat penting. ${ }^{1}$ Dalam penggunaan dua bahasa atau lebihterjadisebuah kegiatan untuk saling mempengaruhi antara bahasa-bahasa tersebut. Hal ini secara otomatis akan menyebabkan beberapa peristiwa yang terjadi dalam pelafalan bahasa-bahasa yang dimiliki diantaranya, diaglosia, alih kode, campur kode, interferensi, integrsi, konfergensi, dan pergeseren makna. ${ }^{2}$ Sebagai salah satu contoh adalah sering terjadinya interferensi bahasa Indonesia ke dalam bahasa Arab, baik itu interferensi fonologi, interferensi gramatikal, maupun interferensi sintaksis.

Berkaitan dengan itu, terdapat beberapa penelitian yang juga membahas tentang kesalahan gramatika yang pernah dilakukan diantaranya oleh Toyyib I.M, dan Hasanatul Hamidah yang melakukan penelitian dengan judul Interferensi Fonologi Bahasa Arab "Analisis Kontrastif Fonem Bahasa Arab Terbadap Fonem Babasa Indonesia Pada Mabasiswa Universitas Al-Azhar Bukan Jurusan Sastra Arab". Penelitian ini menunjukkan bahwa interferensi terjadi karena terdapat banyak fonem-fonem bahasa Arab yang tidak terdapat dalam bahasa Indonesiasehingga terjadi kesulitan dalam pengucapannya. Interferensi juga terjadi karena jarang menggunakan fonem-fonem tersebut dalam sebuah pembicaraan. ${ }^{3}$

Kemudian Muhammad Musa Ali, Ahmad Miftahuddin, dan Darul Qutni melakukan penelitian dengan judul Interferensi Fonologis dan Gramatika Siswa Kelas VII Mts N 1 Kudus Dalam Pembelajaran Bahasa Arab (Kajian Sosiolinguistik). Penelitian ini menunjukkan banyak terjadi sebuah interferensi baik itu dalam sisi fonologis, gramatika, dan sintaksisnya. Dalam penelitian tersebut ditemukan 6 interferensi fonologis, 5 interferensi morfologis, dan 7

${ }^{1}$ I. Dewa Putu Wijana and Muhammad Rohmadi, Sosiolinguistik: Kajian Teori Dan Analisis, Cet. 2 (Yogyakarta: Pustaka Pelajar, 2010), hal. 56. 2010), hal. 84 .

${ }^{2} \mathrm{Abdul}$ Chaer and Leonie Agustina, Sosiolinguistik: suatu pengantar (Jakarta: Rineka Cipta,

${ }^{3}$ Ari Khairurrijal Fahmi, "Analisis Kesalaban Gramatikal Teks Terjemab (Indonesia-Arab) Dalam Pendidikan Bahasa Arab," KORDINAT vol. XV no. 1 (2016): hal. 105-116. 
interferensi sintaksis. ${ }^{4}$ Penelitian Ari Khairurrijal Fahmi dengan judul Analisis kesalahan tejs terjemah (Indonesia Arab) dalam Pendidikan Bahasa Arab yang menghasilkan bahwa kesalahan terjemah terjadi akibat alur berfikir dari penerjemah, kemudian kesalahan terjadi karena pencampuran bahasa, dan kesalah pahaman komunikasi antara penulis.

Kemudian setelah melakukan observasi dan wawancara dengan mahasiswa pascasarjana UIN Sunan Kalijaga ditemukan terjadi beberapa interferensi gramatikal dalam hasil tulisan mahasiswa. Dalam karya tulis mahasiswa dengan menggunakan bahasa Arab masih terdapat beberapa interferensi gramatikal seperti dalam sistematika susunan penulisan Arab. Secara teoritik mahasiswa telah memahami bagaimana sistematika penulisan bahasa Arab, namun dalam pengaplikasian dalam karya tulis mahasiswa masih sering keliru dan mahasiswa masih terbawa oleh sistem penulisan bahasa Indonesia yang menyebabkan masuknya sistematika bahasa Indonesia ke dalam sistematika bahasa Arab khususnya dalam mahārah al-Kitābah. Adapun interferensi yang banyak terdapat dalam tulisan mahasiswa adalah dalam penyusunan jumlah idofiyah.

Dalam penelitian ini peneliti akan membahas tentang peristiwa interferensi. Interferensi merupakan suatu peristiwa yang mengacu pada penyimpangan dalam menggunakan suatu bahasa yang didominasi oleh bahasa ibu dan faktor-faktor yang menyebabkan itu terjadi. Dalam mengucapkan suatu bahasa, penutur memaksakan untuk memasukkan sistem bahasa ibu ke dalam bahasa kedua sehingga terjadi sebuah penyimpangan dalam sistem bahasa kedua. ${ }^{5}$ Interferensi adalah kesalahan berbahasa baik dari segi pengucapan, tata bahasa, kosa kata, makna, dan bahkan budaya dalam pembelajaran bahasa karena disebabkan oleh kecenderungan akan bahasa ibu yang sudah tertanan dan mendarah daging dalam diri penutur bahasa. ${ }^{6}$ Dari pengertian interferensi di atas, bisa dilihat bahwa interferensi bisa terjadi pada semua unsur dan tatanan bahasa ketika seseorang sedang menggunakan suatu bahasa kedua baik dalam ucapan maupun penulisan.

Termasuk juga interferensi bahasa juga bisa terjadi di segi susunan bahasanya (gramatikal). Dalam membuat suatu kalimat banyak pelajar bahasa Arab masih mengikuti kebiasaan dari bahasa pertamanya. Begitupula pada

${ }^{4}$ Muhammad Musa Ala, Ahmad Miftahuddin, and Darul Qutni, “interferensi Fonologi dan Gramatikal Siswa Kelas VII Mts N 1 Kudus Dalam Pembelajaran Bahasa Arab (Kajian Sosiolinguistik," Jurnal Lisanul Arab, 2019, hal. 82-92.

${ }^{5}$ Abdurrahman Abdurrahman, "Sosiolinguistik: Teori, Peran, dan Fungsinya Terbadap Kajian Bahasa Sastra," Lingua: Jurnal Ilmu Bahasa dan Sastra 3 (October 14, 2011), hal. 18-37.

${ }^{6}$ Thoyib Thoyib and Hasanatul Hamidah, "Interferensi Fonologis Bahasa Arab "Analisis Kontrastif Fonem Bahasa Arab Terhadap Fonem Bahasa Indonesia Pada Mahasiswa Universitas Al Azhar Bukan Jurusan Sastra Arab," Jurnal Al-Az̧har Indonesia Seri Humaniora 4, no. 2 (January 31, 2018): hal. 63-71. 
mahasiswa pascasarjan jurusan pendidikan bahasa Arab (PBA) UIN Sunan Kalijaga dalam menyusun tulisan sering terjadi interferensi bahasa dalam hal ini interferensi gramatikal bahasa ibu ke dalam bahasa Arab seperti contoh interferensi yang terjadi diantaranya: صراط السيئ Dalam kalimat ini jika dilihat dari segibentuk jumlah adalah bentuk jumlah idofiyah namun jika diperhatikan lebih seksama lagi, dalam jumlah idofiyah harus terkandung di dalamnya salah satu makna فيtau J sedangkan dalam kalimat tersebut tidak terkandung tidak terkandung salah satu dari makna idofah,tapi maknanya lebih mengarah kepada sifat mausub.

Maka dari itu peneliti ingin mengkaji tentang interferensi gramatika bahasa ibu dalam bahasa Arab dengan tujuan untuk mengetahui dimana saja interferensi gramatikal di kalangan mahasiswa pascasarjana sering terjadi, dan untuk mencari bagaimana solusi untuk meningkatkan maharah kitäbah. Yang juga diharapkan bisa diterapkan pada siswa-siswa pembelajar bahasa Arab pada umumnya.

Penelitian ini adalah penelitian lapangan (field research) dengan menggunakan pendekatan fenomenologi. Sumber datapenelitian ini adalah mahasiswa prodi pendidikan bahasa Arab (PBA) pascasarjana UIN Sunan Kalijaga pada semester ganjil, dengan didukung sumber sekunder yang penulis kumpulkan dari tulisan-tulisan dan hasil penelitian terdahulu yang penulis kumpulkan dari beberapa literatur-literatur yang ada. Tehnik pengumpulan data yang dilakukan peneliti ialah dengan melakukan observasi non partisipan dimana peneliti hanya mengamati saja, wawancara tidak terstruktur, dan melakukan dokumentasi dengan mengumpulkan tulisan dari mahasiswa. Penelitian ini menggunakan metode analisis kesalahan. Dalam hal ini kesalahan dalam bentuk interferensi gramatikal bahasa Indonesia ke dalam baraha Arab.

\section{Hasil dan Pembahasan}

\section{Interferensi Gramatikal}

Bahasa Arab sebagai bahasa kedua memiliki kecenderungan untuk mengikuti susunan dan tata bahasa pertama dalam hal ini adalah bahasa Indonesia. Seperti yang telah disebutkan bahwa hal itu bisa terjadi dikarenakan kebiasaan dalam menggunakan bahasa pertama yang masih belum bisa berubah dan kebiasaan itu sampai masuk dalam penggunaan bahasa ke dua dalam hal ini bahasa Arab. Dalam pembelajaran bahasa hal ini memang sudah sering terjadi terutama di dalam proses awal pembelajaran, hal ini dikarenakan seseorang yang menggunakan dua bahasa kecenderungn penguasaan bahasa yang satu masih 
lebih rendah dari penguasaan bahasa yang lain. ${ }^{\top}$ Tidak hanya dikalangan pelajar awal interferensi juga sering terjadi di kalangan pembelajar bahasa di tinggkat atas, namun dengan persentasi yang lebih kecil. Semakin seimbang penguasaan antara satu bahasa dengan bahasa yang lain maka, akan kebiasaan buruk itu akan semakin jarang dilakukan.

Interferensi bahasa inipun terjadi di kalangan mahasiswa pascasarjana UIN sunan Kalijaga, data ini didapat dari hasil analisa tulisan mahasiswa dalam membuat kalimat dalam bahasa Arab. Berdasarkan hasil analisa terebut ditemukan beberapa interferensi bahasa Indonesia dalam bahasa Arab. Adapun interferensi gramatikal yang terjadi di kalangan mahasiswa pascasarjana UIN sunan kalijaga diantaranya adalah sebagai berikut:

1. Interferensi dalam Isim Mausūl

Isim mausūl adalah isi yang menunjukkan makna "yang". ${ }^{8}$ Isim mausūl adalah sesuatu yang menunjukkan atas suatu kejadian dengan perantaraan jumlah yang terletak setelahnya. ${ }^{9}$ Dari segi fungsi isim mausūl terbagi menjadi dua bagian yang pertama, yaitu isim mausūl yang khusus seperti الَّنِيني (untuk muzakkar mufrad), الَّذَانِ (untuk muzakkar mutsanna), الَّنِيْنَ (untuk muzakkar

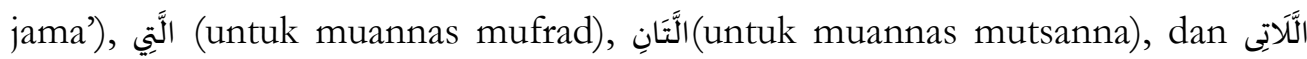
(untuk muannas jama') dan bagian yang kedua adalah isim mausūl yang umum seperti من baik untuk menunjukkan mufrad, mutsanna, jamak, mudzakkar atau muannas bisa menggunakan من namun sebatas untuk sesuatu yang berakal, ذَا, أيٌّ ذُوْا yang bisa digunakan untuk semuanya, baik untuk berakal dan tidak berakal, mudzakkar atau muannas, mufrad, mutsanna, maupun jamak boleh menggunakan kalimat tersebut. ${ }^{10}$

Dari penjelasan di atas bisa diketahui bahwa isim mausūl ada yang memiliki fungsi khusus dan adapula yang memiliki fungsi ganda, namun dalam penggunaannya sering sekali banyak yang mencampur adukkan antara gramatika Indonesia dalam bahasa Arab seperti contoh yang ditemukan dalam hasil analisa tulisan mahasiswa diantaranya:

${ }^{7}$ Musa Ala, Miftahuddin, and Qutni, "Interferensi Fonologi dan Gramatikal Siswa Kelas VII Mts $N 1$ Kudus Dalam Pembelajaran Bahasa Arab (Kajian Sosiolinguistik), Lisanul Arab: Vol 8 No 1 (2019), hal. 82-92"

${ }^{8}$ Taufiqul Hakim, Program Pemula Membaca Kitab Kuning Amtsilaty Jilid 1, Jepara: al-Falah Offset, 2013), hal. 43.

${ }^{9}$ Mustofa al-Gulābini, Jāmi' al-Durūs al-Arobiyah jilid 1, (Libanon: Dār Al-Kitāb AlAmali, 2011), hal. 98.

${ }^{10}$ Muhammad Ibnu Ahmad Ibnu Abdul Bāri Al-Ahdal, al-Kawākibu al-Duriyah (Libanon: Dār al-Kitāb al-Amali, 2015), hal. 127. 
dalam percakapan tersebut penulis ingin menanyakansiapa nama seseorang yang telah menaruh nasi dan roti di depan rumah.

Dari contoh ungkapan kalimat tersebut, bisa kita lihat bahwa masih terjadinya interferensi bahasa dalam penggunaan isim mausūl yaitu penulis masih tidak memperhatikan jenis isim mausul yang digunakan, dalam kalimat اسم الَّندي isim mausūl yang harusnya digunakan adalah التي karena yang dimaksud oleh mausūl itu adalah seorang wanita yang ditandai dengan adanya dhomir untuk muannas yang terletak pada kalimat sebelumnya yaitu (اسمها). Maka ungkapan yang benar adalah هل عرفت اسمها ؟ اسم التي وضعت الرز و الخبز أمام البيتي .

Agar lebih memudahkan pemahaman penulis memberikan sebuah tabel tentang kesalahan dan pembenarannya, yaitu:

\begin{tabular}{|r|r|l|}
\hline Kesalahan & Pembetulan & \multicolumn{1}{|c|}{ Bentuk kesalahan } \\
\hline هesan & هesalahan pemilihan \\
dan penggunaan isim \\
mausūl
\end{tabular}

2. Interferensi dalam Membuat Jumlah Idhafiyah

Iḍāfah secara bahasa berarti bersandar. Iḍāfah dalam istilah ilmu nahwu adalah jumlah yang terdiri dari dua isim atau lebih yaitu isim yang pertama disebut "muḍāe" dan isim yang kedua disebut "muḍāfun ilaih" "I I⿳亠̄āfah adalah menyandarkan antara dua kalimat isim dengan mentakdirkan huruf jar, dan wajib membaris bawahkan kalimat yang kedua. ${ }^{12}$ Iḍāfah adalah menghubungkan antara minimal dua kalimat isim atau lebih yang memiliki makna yang berbeda menjadi saling terkait sehingga menghasilkan makna yang satu. Contoh iḍāfah: رسول الله

Dalam membuat sebuah ị̣āfah ada beberapa syarat yang harus dipenuhi antara lain yaitu:

a. Kalimat pertama (mudhaf) tidak boleh memiliki tanwin, tidak boleh ber alif lam, dan tidak boleh memiliki nun

b. Kalimat yang kedua hukumnya harus jar.

Syarat-syarat tersebut sesuai dengan syair Ibnu Malik yaitu :

$$
\begin{aligned}
& \text { نونا تلي الإعراب او تنوينا \# مما تضيف احنف كطور سين }
\end{aligned}
$$

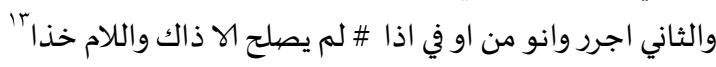

\footnotetext{
${ }^{11}$ Hakim, Program Pemula Membaca Kitab Kuning Amtsilaty Jilid 1, hal. 13.

${ }^{12}$ Al-Gulābini, Jämi' al-Durūs al-Arobiyah jilid 1, hal. 159.

${ }^{13}$ Taufiqul Hakim, Program Pemula Membaca Kitab Kuning Kbulasob Alfiyab Ibnu Malik (Jepara: Al-Falah Offset, 2013), hal. 4.
} 
Dari syair tersebut juga bisa dilihat bahwa dari segi makna, idhafah haruslah mengandung salah satu dari tiga makna yaitu makna من , makna J, dan makna في contoh: خاتم حديد اي (خاتم من حديد artinya cincin besi (cincin dari besi)

artinya pelayan ari (pelayan milik ari) ramadhan)

artinya puasa ramadhan (puasa di bulan

Secara penguasaan teori para mahasiswa memang sudah mengetahuai semua penjelasan di atas, namun dalam hasil analisa tulisan yang dbuat oleh para mahasiswa masih banyak ditemukan kekeliruan dalam membuat suatu ungkapan diantaranya:

Dalam kalimat هدي العلماء الناس إلى طريق الخير dalam ungkapan tersebut penulis ingin mengungkapkan bahwa ulamak itu memberi petunjuk kepada jalan yang baik. Namun, untuk mengungkapkan makna "jalan yang benar" penulis menggunakan jumlah iộ̄fah yang dalam konteks makna yang diinginkan tidaklah sesuai dengan ketentuan-ketentuan iḍāfah, dimana dalam kalimat طريق

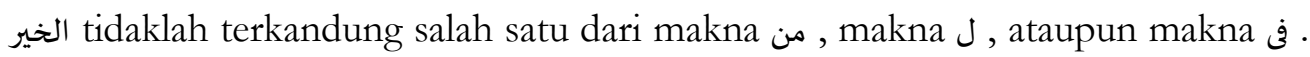
kalimat tersebut secara makna lebih cocok dibentuk dengan menggunakan jumlah wașfiyah, yaitu jumlah sifat dan maușuf. Maka kalimat yang benar untuk mengungkapkan ungkapan tersebut ialah هدى العلماء الناس إلى الطريق الخير dalam hal ini kalimat الطريق الخير tidaklah dalam bentuk iḍ̄āfah, melainkan dengan menggunakan susunan sifat mauṣuf.

Dalam kalimat يثبت عثمان الإستقامة على صراط الحميد seperti halnya penjelasan diatas, dalam kalimat صراط الحميد tidak cocok dibuat dengan susunan iḍāfiyah melainkan kalimat tersebut lebih benar jika disusun dengan susunan sifat maușub yaitu ungkapan tersebut seharusnya berbunyi:" يثبت عثمان الإستقامة على الصراط" "الحميد"

Untuk menpermudah pemahaman maka penulis membuat tabel tentang bentuk kesalahan dan pembenarannya, yaitu sebagai berikut:

\begin{tabular}{|c|c|c|}
\hline Kesalahan & Penbetulan & Bentuk kesalahan \\
\hline إلي طريق الخيد & هدى العلماء الناس إلى الطريق & $\begin{array}{l}\text { Kesalahan dalam } \\
\text { pembentukan susunan } \\
\text { jumlah }\end{array}$ \\
\hline يثبت عثمان الإستقامة على صراط & الصبراط الحميد عثمان الإستقامة على & $\begin{array}{l}\text { Kesalahan dalam } \\
\text { pembentukan susunan } \\
\text { jumlah }\end{array}$ \\
\hline
\end{tabular}




\section{Interferensi dalam Penggunaan Fïil}

Fi'il menurut bahasa adalah kata kerja. Fiil merupakan suatu peristiwa yang terjadi di waktu tertentu baik itu masa lampau, sedang terjadi, atau akandatang. Fi'il terbagi menjadi tiga yaitu fi'il madhi (kata kerja pada masa lampau), fi'il mudhari' (kata kerja yang sedang terjadi atau akan datang), dan fi'il 'amr (kata perintah). Contoh: ضضرب (telah memukul) يضرب (sedang atau akan memukul) اضرب (pukullah)

Beberapa interferensi yang terjadi dalam penggunaan fill adalah dalam kalimat يغضي عليا أمي غضبا لأنني نائما في الصبح ولمأصلي dalam ungkapan tersebut penulis ingin memceritakan bahwa ibunya telah memarahinya karena tidak sholat subuh tadi pagi, namun dalam penggunaan fillnya masih ada kekeliruan yaitu dalam ungkapan tersebut penulis menggunakan fiil muḍārik yang mengandung makna sedang atau akan terjadi, sehingga maknanya berubah menjadi ibu sedang atau akan memarahiku karena tidur dan tidak sholat subuh. Sedangkan makna yang dimaksud oleh penulis ialah bahwa ibunya telah memarahinya yaitu suatu kejadian pada masa lampau. Kalimat يغضب yang seharusnya menggunakan fi'il madhi yang menunjukkan makna kejadian pada masa lampau, hal ini terjadi karena kebiasaan penuturan di bahasa Indonesia tidaklah sedetail itu. Maka نضب عليا أمي غضبا لأنني نائما في الصبح ولمأصلي ungkapan yang seharusnya digunakan ialah

Dalam kalimat المحبون ينتظر في الملعب dalam ungkapan tersebut penulis ingin mengungkapkan bahwa para penggemar sedang menuggu di lapangan. Secara makna ungkapan tersebut memang terkesan benar namun secara susunan kaidah dalam bahasa Arab ungkapan tersebut terkesan keliru dan terinrerferensi oleh struktur tata bahasa Indonesia. Kalimat ينتظر adalah bentuk fiil yang menunjukkan fäil-nya tunggal atau hanya satu, kalimat ينتظر fäilnya adalah dhamir المحبون yang menujukkan mufrad atau tunggal dan akan kembali kepada kalimat yang merupakan kalimat dalam bentuk jamak sehingga nampak antara ḍāmir dan murojiknya tidak sesuai.

Ungkapan tersebut harusnya berbunyi المحبون ينتظرون في الملعب yang memiliki makna para penggemar sedang menunggu di lapangan. Dalam unkapan ini fail dari kalimat ينتظرون adalah dhomir همang menunjukkan jamak dan kembali kepada kalimat المحبون yang juga menunjukkan jamak.

Untuk lebih memahaminya lihat tabel berikut:

\begin{tabular}{|c|c|c|}
\hline Kesalahan & Pembenaran & Bentuk kesalahan \\
\hline يغضيب عليا امي لأنني نائما في & غضب عليا امي لأنني نائما في الصبح & Kesalahan bentuk fi'il \\
\hline ت ع ولمأصلي & & \\
\hline المحبون ينتظر في الملعب & المحبون ينتظرون في الملعب & Kesalahan bentuk fi'il \\
\hline
\end{tabular}




\section{Interferensi dalam Pengggunaan Hurf}

Huruf dalam bahasa Indonesia adalah kata penghubung. Dalam ilmu nahwu huruf adalah suatu kalimat yang tidak menunjukkan makna suatu kejadian padanya dan tidak pula mengandung makna waktu. Huruf ada yang khusus masuk pada isim, ada yang masuk khusus pada fill, dan ada yang masuk pada isim dan fiil.

Interferensi penggunaan huruf yang dimaksud dalam hal ini adalah interferensi penggunaan huruf jar. Huruf jar merupakan huruf yang khusus masuk kepada kalimat isim. Interferensi yang temukan dalam penggunaan huruf jar yaitu pada ungkapan أذكر ما أعطى الله إلى في حياتي dalam ungkapan ini penulis ingin mengungkapkan bahwa penulis mengingat apa yang telah diberikan Allah ke dalam hidupnya. Dalam tata bahasa Arab menggandengkan antara dua huruf merupakan sesuatu yang salah dan tidak diperbolehkan. Seharusnya dalam ungkapan ini penulis hanya menggunakan satu huruf jar saja.

Dalam bahasa indonesia kata "ke" merupakan kata penghubung, begitupula dalam bahasa Arab kata "ke" juga merupakan kata penghubung, sedangkan kata "dalam" di bahasa Indonesia termasuk juga ke dalam kata tempat, dan dalam bahasa Arab kata "dalam (ف)" termasuk ke dalam kata penghubung. Maka terlihat dalam ungkapan tersebut penulis membawa struktur susunan bahasa Indonesia ke dalam bahasa Arab.

\begin{tabular}{|c|c|l|}
\hline Kesalahan & Pembenaran & Bentuk kesalahan \\
\hline أذكر ما أعطي الله في حياتي & $\begin{array}{l}\text { Kesalahan karena } \\
\text { menggunakan dua huruf } \\
\text { jar }\end{array}$ \\
\hline أعطي الله الي في حياتي & \\
\hline
\end{tabular}

\section{Penyebab terjadinya interferensi pada mahasiswa}

Setelah menganalisa data-data yang ditemukan, ternyata permasalahan interferensi gramatikal di kalangan mahasiswa UIN Sunan Kalijaga masih sering terjadi walaupun dengan persentasi yang kecil. Fakta bahwa di mahasiswa masih terjadi interferensi tidak bisa dibantahkan, walaupun setelah ditanya tentang tulisan yang dibuat mahasiswa menyadari bahwa dalam tulisannya masih terjadi kekeliruan, yaitu masih terjadi interferensi dalam gramatikalnya. Hal itu dibuktikan dengan mahasiswa yang secara teori telah memahami kaidah-kaidah gramatikal yang dalam penulisannya masih mengalami interferensi.

Kemudian setelah melakukan penelitian lebih mendalam tentang terjadinya interferensi gramatikal yang secara teori telah diketahui oleh mahasiswa yang melakukan interferensi maka, peneliti menemukan suatu titik temu di antara para mahasiswa, hal itu terkait dengan sosiohistoris dari para mahasiswa. Mahasiswa yang berasal dari berbagai daerah dan merupakan alumni dari berbagai pondok pesantren mengalami hal yang mirip ketika proses 
pembelajaran nahwu sharaf di sekolah sebelumnya. Dalam proses pembelajaran nahwu sharef mereka mengaku jarang disuruh membuat contoh kalimat terkait materi yang dipelajari, mereka lebih banyak menganalisa contoh-contoh yang diberikan.

Selain itu ada juga beberapa mahasiswa yang dalam proses pembelajarannya di sekolah sebelumnya banyak tak hanya disuruh menganalisa contoh kalimat tapi mereka juga ditugaskan untuk membuat karangan mengenai materi yang diajarkan dan bahkan sekolah yang sebelumnya mewajibkan penulisan skripsi dengan bahasa Arab. Mahasiswa yang dalam pembelajaran hanwu sharefnya sering ditugaskan untuk membuat contoh kalimat memiliki persentasi melakukan interferensi gramatikal lebih kecil dari pada mahasiswa yang lain.

Dari data-data di atas maka, bisa diambil kesimpulan bahwa salah satu faktor yang menyebabkan terjadinya interferensi gramatikal adalah sistem dan metode pembelajaran nahwu sharef yang kurang tepat. Dimana banyak pondok pesantren dalam mengajarkan nahwu sharaf lebih sering memberikan tugas untuk menganalisa contoh dari pada tugas untuk menbuat contoh kalimat. Hal ini terbukti berpengaruh dalam perkembangan peserta didik pada masa depan seperti halnya yang terjadi pada mahasiswa yang melakukan interferensi gramatikal.

\section{Penutup}

Hasil dari penelitian yang dilakukan ini menunjukkan bahwa interferensi gramatikal yang terjadi dalam tulisan mahasiswa diantaranya terjadi dalam penggunaan isim mausbul yang berjumlah 1 interferensi, kemudian interferensi dalam pembentukan jumlah idhafiyah, yang berjumlah 5 interferensi, kemudian interferensi dalam penggunaan fíll, yaitu pada berjumlah 4 interferensi, dan interferensi dalam penggunaan huruf jar yaitu pada satu kalimat. Kemudian faktor yang menyebabkan terjadinya interferensi gramatikal di kalangan mahasiswa pascasarjana adalah sistem dan metode dalam pembelajaran nahwu sharef yang kurang tepat yang dialami mahasiswa di sekolah asal mereka, yaitu sistem pembelajaran yang lebih sering melakukan analisa contoh terkait materi yang diajarkan dari pada membuat contoh dari materi yang diajarkan. Berkaitan dengan itu pengkajian tentang interferensi gramatikal bahasa Arab dalam mabarah al-kitabah perlu dilakukan pengembangan secara lebih luas dan mendalam. Kemudian salah satu cara yang bisa dilakukan untuk menaggulangi permasalahan ini adalah dengan lebih sering melakukan latihan menyusun kalimat bahasa Arab dengan lebih memperhatikan kaidah-kaidah yang telah dipelajari sebelumnya. 


\section{Bibliografi}

Abdurrahman, Abdurrahman. "Sosiolinguistik: Teori, Peran, Dan Fungsinya Terhadap Kajian Bahasa Sastra." Lingua: Jurnal Ilmu Bahasa Dan Sastra 3 (October 14, 2011).

Al-Gulābini, Mustofa. Jāmi' Al-Durūs Al-Arobiyah jilid 1. Libanon: Dār Al-Kitāb Al-Amali, 2011.

Chaer, Abdul, and Leonie Agustina. Sosiolinguistik: suatu pengantar. Jakarta: Rineka Cipta, 2010.

Fahmi, Ari Khairurrijal. "Analisis Kesalahan Gramatikal Teks Terjemah (Indonesia-Arab) Dalam Pendidikan Bahasa Arab,” no. 1 (2016): 13.

Hakim, Taufiqul. Program Pemula Membaca Kitab Kuning Amtsilaty Jilid 1. Jepara: Al-Falah Offset, 2013.

- Program Pemula Membaca Kitab Kuning Kbulasoh Alfiyah Ibnu Malik. Jepara: Al-Falah Offset, 2013.

Ibnu Abdul Bāri Al-Ahdal, Muhammad Ibnu Ahmad. Al-Kawākibu Al-Duriyah. Libanon: Dār Al-Kitāb Al-Amali, 2015.

Musa Ala, Muhammad, Ahmad Miftahuddin, and Darul Qutni. “interferensi Fonologi dan Gramatikal Siswa Kelas VII Mts N 1 Kudus Dalam Pembelajaran Bahasa Arab (Kajian Sosiolinguistik." Jurnal Lisanul Arab, 2019, 82-92.

Thoyib, Thoyib, and Hasanatul Hamidah. "Interferensi Fonologis Bahasa Arab 'Analisis Kontrastif Fonem Bahasa Arab Terhadap Fonem Bahasa Indonesia Pada Mahasiswa Universitas Al Azhar Bukan Jurusan Sastra Arab." Jurnal Al-Az̧har Indonesia Seri Humaniora 4, no. 2 (January 31, 2018): 63-71.

Wijana, I. Dewa Putu, and Muhammad Rohmadi. Sosiolinguistik: Kajian Teori Dan Analisis. Cet. 2. Yogyakarta: Pustaka Pelajar, 2010. 
48 | Arabiyatuna : Jurnal Bahasa Arab, Vol. 4, No. 1, 2020 